\title{
Dividend Policy, Share Price and Future Profitability: Case of Commercial Banks in Nepal
}

\author{
Nabina Dhakal ${ }^{12}$ and Ajay Shah ${ }^{13}$
}

\begin{abstract}
The study analyzes the impact of dividend policy on share price and future profitability of commercial banks in Nepal. Using panel secondary data of 13 commercial banks from year 2001 to 2014, correlation and regression analysis are appliedfor the study. The impact of dividend policy on share price is analyzedfirst and the findings of initial analysis suggests that dividend yield and retention ratio have significant negative impact, whereas earning per share has significant positive impact on share price. The study, thus, supports the dividend relevance in Nepalese capital market, and it is further extended to analyze whether dividend changes carried any special information influencing future profitability of commercial banks in two subsequent year of dividend declaration. The conclusion from the analysis indicatesthat the current year dividend change has significant impact on current year earning changes. For subsequent years, the impact of dividend change is insignificant. Thus, dividend change does not carry information regarding changes in earning in subsequent years of dividend declaration and does not support signalling hypothesis in Nepalese capital market.
\end{abstract}

Keywords: Cash Dividend, Dividend Yield, Retention Ratio, Earning Per Share, Dividend Signalling

\section{Introduction}

The term dividend is known as the return distributed by the firm, in terms of cash, shares and other forms of the earning of the shareholders for their investment in share capital. It is the means by which cash comes out of the company and goes to shareholders in the capital market. For any investor who invests their money in securities of any companies, the return would be dividend earning or the appreciation in value of shares through capital gain. Hence, in the capital market, one of the important financial decisions is the allocation of earnings into two sections i.e. dividend and/or retained earnings. For this, each firm should

12 Ms. Dhakal is currently working as a Senior Assistant in Nepal Bank Limited, KTM,Nepal

13 Mr. Shah is a Ph.D. scholar in Kathmandu School of Management, KU, and Director of MBA program in Ace Institute of Management.

Corresponding email: nabinadhakal2000@gmail.com 
accurately decide the amount of dividend that should be distributed among the stockholders and the amount of earnings to be retained in the organization. This scenario of deciding about the rate of divided/ retained earning constitutes the basic concept of dividend policy. Dividend policy, thus, refers to management's longterm decision on how to deploy cash flows from business activities that is, how much to invest in the business, and how much to return to the shareholders. As per Irandoost (2013), the primary objective of financial management of firms, i.e. the wealth maximization of stockholders, the decision towards the allocation of firms earning should ultimately be to increase the shareholders wealth. Every firm operating in a given industry follows some sort of dividend payment pattern or dividend policy, which is obviously a financial indicator of the firm. Thus, demand of the firm's share price should be, to some extent, dependent on the firm's dividend policy (Masum (2014). The relation of dividend and share prices has been one of the greatest puzzles in finance and there is no satisfactory conclusion regarding the relationship between these two. A group of researchers like Miller and Modigliani (1961), Baker et al. (1985)view dividend policy as irrelevance which means dividend policy has no effect on either the stock price or its cost of capital. Another group of researchers like Walter (1956), Gordon (1963) argue that dividend payment carry special information leading to rise in share prices. Similarly, another group of researchers like Pettit (1972) argue that dividend payments lead to decrease the stock price, and hence reducing the value of firm.

Despite the number of researches and theories propounded in the area of dividend, there is no satisfactory conclusion regarding the impact of dividend on share price.The theories and explanations that have emerged have resulted in an enormous theoretical and empirical body of research with several hundred monographs, working papers, and journal articles. The puzzles of dividend and share price, therefore, motivate researchers to study the relation between these two in context of Nepalese financial market.

Among all, the implication of dividend policy to be adopted by the company on its share price is one of the crucial and difficult decisions that management of any business face. Besides, it is equally important to identify the pattern and size of dividend distribution. However, the patterns of corporate pay-out policies not only vary over time but also across the countries, especially between developed and emerging capital markets. Developed capital markets are stable and predictable providing investors a confidence to make investment. As such developed capital market witnesses better business environment by providing ample investment opportunities to both individual investor as well as business firms. In contrast, emerging and underdeveloped capital market, like Nepalese capital market, witnesses several financial constraints and limited investment opportunities. 
Besides, number of shares traded and players in the markets are also limited. Due to limited investment opportunity, firms tend to focus more on retaining profits, which result into lowering the pay-out ratio.

However, in recent days, the phenomenon of dividend declaration has been frequent in Nepalese capital market. After the economic liberalization and globalization, large number of companies started operation in Nepal and the case of dividend distribution has also increased thereafter. This motivates finance scholars and researchers to study the impact of dividend on the company's financial indicators. This research is also based on understanding the impact of dividend distribution on Nepalese financial market and researchers are motivated to put light on the present scenario of dividend distribution, the impact of dividend policy on share price, and future profitability of commercial banks in Nepal.

A number of prior studies have been conducted in recent days in the area of dividend policy and stock price volatility in Nepal. As per Adhikari (2014), the most important determinants of dividend policy of Nepalese enterprises, in order, are growth rate of enterprise's earnings, patterns of past dividends, and availability of investment opportunities. Besides, he also argues that managers have more emphasis on the stable dividend policy and dividend is considered to be a significant variable for stock price movement in Nepal. Despite prior studies, the industry wide and in-depth analysis of dividend policy and stock returns has not been conducted. Most of the researches concentrated on one or two institutions/sectors with one or two variables only. The inferences drawn from such studies raise the question of applicability for the entire market. Besides, to the best of the knowledge of researchers, no prior studies on dividend have analyzed the impact of dividend change on future profitability of organizations.

Among the players in Nepalese capital market, banks and financial institutions predominate over others in the stock market transaction (Koirala \& Bajracharya). Banking sector, in the eye of the buyers, looks safest for the stock exchange followed by other financial institutions like insurance companies, finance companies, hydropower, hotels, etc. As such financial sector occupies a major share in Nepalese capital market and also in the research discipline of corporate finance. Researchers also choose banking sector in their research and analyze the impact of dividend policy on the share prices, and examine if divided signalling hypothesis is applicable in Nepalese financial market. Dividend signalling hypothesis, here, implies that dividend declaration carries special information and has impact on share prices.

Thus, the research objective of the study is to identify the impact of dividend policy on share prices and future profitability of commercial banks and to analyze 
whether dividend changes carry signalling hypothesis in the context of Nepalese banking industry. The study has thus identified three basic research question; (i) How significant is the impact of dividend policy on share prices of different commercial banks? (ii) What is the relationship between change in dividend and earnings? (iii) Do dividend changes convey information about future profits?

The study however has some limitations. (i) The sample of the study covers only dividend paying commercial banks and only cash dividend paying commercial banks. The study excludes the bonus share as a dividend distribution.(ii)The study period is from 2001 to 2012, but for some banks only 3 or 4 fiscal years have been taken due to unavailability of data. And out of 30 commercial banks, 13 commercial banks that are paying cash dividend regularly in the study period are taken as sample for study.(iii)The range of DW test is assumed to be within 1-2.5 instead of 1.5-2.5.(iv.) The study is mostly based on secondary data. Therefore, the findings of the study solely depend on the reliability of such data.

The study identifies share prices of commercial bank as dependent variables and dividend yield, retention ratio, profit after tax, earning per share, and return on equity as independent variables. The basic model is modified leaving two variables i.e. return on equity and profit after tax since these variables have insignificant impact on share price.The independent variables i.e. dividend yield, retention ratio and earnings per share has direct impact on the share price. This indicates the dividend relevancy in Nepalese banking sector. However, in case of dividend changes, it has significant impact on profitability of respective year of dividend declaration. In subsequent year 1 and 2 of dividend declaration, the changes in dividend have insignificant impact. Thus, in the context of Nepalese banking industry, the dividend-signalling hypothesis is not applicable.

\section{Review of Literature}

The dividend policy of a company determines what proportion of earnings is distributed to the shareholders by way of dividends, and what proportion is ploughed back for reinvestment purposes. Dividend policy connotes pay-out policy, which managers pursue in deciding the size and pattern of cash distribution to shareholders over time (Waithaka and etal. (2012)). Since the main objective of financial management is to maximize the market value of equity shares, one key area of study is the relationship between the dividend policy and market price of equity shares. However, dividend policy is considered as one of the most controversial issue in corporate finance over a long period of time. Different group of researchers view dividend policies differently. Miller and Modigliani (1961) argued that in a perfect market regardless of how the firm distributes its income, its value is determined by its basic earning power and its investment decisions and 
further state that given a firm's investment policy, the dividend pay-out policy firm choices will affect neither the current price of its shares nor the total returns to shareholders. Similarly,Black and Scholes (1970) argue that dollar of dividends has the same value as a dollar of capital gains in the market and there are virtually no differential returns earned by investors who buy high dividend yielding securities or low dividend yielding securities once they control the crucial risk variable. The research byBlack and Scholes (1974) further emphasizes that dividend policy does not have significant relation with common stock prices. There are other group of researchers like Bhole (1980), Ali and Chowdhury (2010), and Grullon and et al. (2005), who are of the view that dividend policy is irrelevant in determining share prices and dividend changes contain no information about future earning changes. As such, any variation on share prices cannot be explained well by dividend policies.

However, another group of researchers have argued that corporate dividend is relevant which leads to increase in the wealth of stockholders through its influence on firm's stock price. Rresearchers like Walter (1956) and Gordon (1963) have very scholarly studied the significance of the relationship between internal rate of return $(\mathrm{R})$ and cost of capital $(\mathrm{K})$ in determining optimum dividend policy of companies and ultimately the impact of such dividend policy on value of the firm. The gist of both dividend models is that when the internal rate of return (R) is higher than cost of capital $(\mathrm{K})$, share price would increase by decreasing the dividend pay-out, when $\mathrm{R}$ is lower than $\mathrm{K}$, then stock price would increase by increasing dividend pay-out. In case both $\mathrm{R}$ and $\mathrm{K}$ are the same, the dividend policy would be irrelevant in stock prices. Both the model thus argues that dividend policy would increase the share price given the financial condition of the firm. Asquith and Mullins (1983) also, in their study, found positive relationship between dividend and share prices and inforce the view that dividend convey unique, valuable information to investors. WasfiAlTroudi and Maysa'aMilhem (2013), also in their research on The Relationship of Cash Dividends, Retained Earnings and Stock Prices, found a positive and significant relationship between study variables. The result of positive and significant relationship between cash dividends and the stock prices imply that the cash dividends per share might lead to increase the closing price of the firm's stock. Hence, the study supports the information-signalling hypothesis of dividend indicating changes in share prices with change in dividend declaration. Dhillon and Johnson (1994) conducted a study on Effect of Dividend Changes on Stock and Bond Prices and finding of the study explained a positive reaction to large dividend increases in the stock market and a negative price reaction in the bond market. 
However, many of the researchers believe that it is the unexpected changes in the dividend that influence the stock prices than the normal dividend. Based on this view also known as behavioural model, researchers assume there exists a target dividend level toward which managers adjust and also assume that managers minimize the costs of adjustment associated with being away from their target dividend pay-out. Garrett and Priestley (2000) followed Lintner (1956) model in their study and found significant evidence of dividend smoothing and dividends conveying information regarding unexpected positive changes in current permanent earnings. Further, the study of the effect of unexpected dividend changes on the values of common stock, preferred stock, and bonds by Woolridge (1983) found that in case of common stock positive (negative) dividend change announcements produce positive (negative) common stock returns whereas unexpected dividend increases (decreases) are associated with positive (negative) debt and preferred stock returns. As such managers of firms follow dividend policy to have the intended influence on the stock prices. However, the research on whether managers rely on dividends to obtain a higher price in a stock offering conducted by Loderer and Mauer (2002), find insignificant relation between dividend announcement and subsequent changes in share prices and conclude that dividend does not provide any valued information to managers.

To Baker and et al. (2006) the most important factors influencing the dividend policy is earnings, specifically the level of current and expected future earnings as well the stability of earnings. Accordingly managers aim at maintaining a specified level of target dividend and there won't be any changes in dividend policy until managers can see that the new earning level is sustainable. According to Eriotis (2005) firms set their dividend policy not only by the net distributed earnings, but also by the change from the last year's dividend, the change from the last year's distributed earnings and the size of the firm.

To be more specific, among different variables of dividend policy two variables, dividend yield and dividend pay-out have been deeply researched in dividend policy discipline. Dividend yield means the ratio of dividend per share to market price per share, which indicates the amount of returns in the form of dividend that investor earn by one rupee investment in share whereas, dividend pay-out ratio measures the percentage of net income that is distributed to shareholders in the form of dividends during the year. Habib and et al. (2012) examine the relationship between dividend policy measure i.e. dividend yield and pay-out ratio and share price volatility in Pakistani stock market. The findings of regression analysis showed the positive relationship of share price volatility with dividend yield, but negative with pay-out ratio. Hashemijoo and et al. (2012) also conducted similar research in Malaysian stock market and the findings of research showedsignificant 
negative relationship between share price volatility with two main measurements of dividend policy, which are dividend yield and dividend pay-out.

The effect of dividend policy on market share value in the banking industry has been researched by Mokaya and et.al (2013) and the result of statistical analysis indicates that formal dividend policy gives shareholders the assurance of predictable dividend payments, and considers payment of dividends as a major element in the value of shares. The study also reveals that dividend payments are better signals of confidential information than other media forms, thus raising share value. The result further indicates that payment of dividends is a demonstration that the firm is strong enough and can pass up profitable investments. Al-Hasan (2013) evaluates the effect of dividend policy on share price of some selected listed companies in Bangladesh taking dividend per share and retained earnings per share as independent variables. The finding of the study suggests a positive relationship of the market price per share with both independent variables. The result also indicates that highly pay-out industries had more market price per share than low pay-out industries. The study has proved that there was a significant effect of dividend policy on market price per share, which supports the relevance theory of the dividend policy.

However, Pettit (1972) has argued that dividend payments lead to the decrease in wealth of shareholders by reducing stock price, and hence decreasing firm value. The recent study of Irandoost (2013) suggests that dividend payment may be contrary to shareholders interest. The payment of dividends results in the reduction of cash, and therefore, is a depletion of total assets. Distribution of profits causes reduction in internal resources and an increase in the need for external resources.If the firm were unable to raise external funds, its growth would be affected. Thus, dividends imply outflow of cash and lower future growth. In other words, the dividend policy of the firm affects both the shareholders' wealth and the long-term growth of the firm. The optimum dividend policy should strike the price of the firm's shares. Although the payments of dividends directly benefit the stockholders, it affects the firm's ability in accumulating profits in order to take advantage of growth opportunities.

As such large numbers of researches have been conducted in the area of dividend around the globe. However, dividend and its impact on key variables of respective companies is still a controversial issue. In this regard, the situation in the Nepalese capital market is in its initial phase, since the economy itself is in the emerging condition. In developing economies like Nepal, the market is small, imperfect and witnesses very few players. In such market condition, the relationship between dividend and share prices is even more intense. Miller and Modgliani (1961) states that if the market is imperfect, dividend may affects stock price. In this scenario, 
with small number of companies/industries operating and very few cases of dividend distribution, Nepalese capital market is far below in the discipline of dividend and corporate finance. In recent times, number of studies has been initiated and attempts have been made by researchers to put light on the area of dividend in the Nepalese context. Despite these researches, dividend policy and its relation to share prices is still a researchable area. The study area/population, study sample, methodology applied, research variables, the duration of the study, etc., differ among researches. In the context of Nepal, a number of researches have been conducted to examine the impact of dividend policy on share prices. However, these studies basically concentrate on selected one or two institutions with one or two variables. The reference drawn from such studies raises the question of applicability for the entire market. Besides, to the best of the knowledge of researcher, no prior studies on dividend have been extended to analyze the impact of change in rate cash dividend distribution on future profitability of the organization. Thus, through this study, researchers aim to throw some light on the dividend policy and its impact on share price and future profitability of commercial banks in Nepal by covering wider study period and larger sample size, and also apply scientific approaches of analysis by applying relevant statistical tools.

Besides, the researchers also aim to provide insight into the newer area in the context of corporate finance in Nepal i.e. dividend policy and its impact on future profitability of commercial banks in Nepal.

\section{The Methodology}

\subsection{The Basic Theory}

All companies with share capital follow some sort of dividend policies. Shareholders being the owners of the company expect fair returns from the company for their investment. It is not only the profit that has attracted the buyers but also the capital gainsthat arise within a short period of time. Thus buyers not only take into account the profit that the company, but also its capital gain while making the buying decision. Having the primary objective of wealth maximization, companies are always interested to know which factors influence their stock price movement and how their dividend policy influences the share price.

Besides, the payment and size of dividendshave been matters of debate in corporate finance. Under conditions of symmetric information and taxes, dividends have been dubbed a puzzle. Several authors model dividend policy under the assumption that information is distributed asymmetrically between managers and investors. Some researchers argue that firms pay dividends because dividends signal the private information of managers and thus help market participants value the firm. The basic idea is that firm managers possess private information about future 
earnings and they like it to convey to the market. However, they cannot simply announce their expectations of future earning publicly because of the fear of imitation by other companies. The information is conveyed by a costly signal i.e. financing of a committed level of dividend, investment and tax on dividends.

Thus, the information content, or signalling, effect relates to the fact that investors regard an unexpected dividend change as a signal of management's forecast of future earnings. A dividend cut is usually interpreted as a negative signal by investors. An unexpected increase in dividends is usually interpreted as a positive signal by investors.

\subsection{The Conceptual Model}

The study followed two proven model for the analysis. The study by Masum (2014) has been used as key paper for this study to identify the impact of dividend on share prices of commercial banks in Nepal. The study variables of the model are most relevant in the area of dividend policy i.e. divident yield, retention ratio, profit after tax, return on equity etc. Besides, the model is well tested in developing country (Bangladesh) which has similar financial market as in Nepal and lastly Masum (2014) has selected commercial banks as the study area like the researcher of this article has choosen.

The first model of this study is:

$M P=\beta 0+\beta 1(D Y)+\beta 2(R R)+\beta 3(P A T)+\beta 4(E P S)+\beta 5(R O E)+\eta+\lambda+\varepsilon$ (i)

Where,

$$
\begin{aligned}
& \mathrm{MP}=\text { Market price } \\
& \mathrm{DY}=\text { Dividend yield } \\
& \mathrm{RR}=\text { Retained ratio } \\
& \mathrm{PAT}=\text { Profit after tax } \\
& \mathrm{EPS}=\text { Earnings per share } \\
& \mathrm{ROE}=\text { Return on equity }
\end{aligned}
$$

The findings of this study indicate that most of the variables of the regression model of this study have significant impact on stock prices. The findings indicate that earnings per share and return on equity have positive relation with stock prices and significantly explain the variations in the market prices of shares, while the dividend yield and profit after tax has negative and significant impact on stock prices. However, retention ratio has a negative but statistically insignificant 
relationship with stock market prices. Thus, the overall results of this study support the statistically significant impact of dividend policy on stock prices.

Supporting the information content of dividend hypothesis, the study further followed the model by Nissim and Ziv (2001) to examine the impact of dividend changes on future profitability of commercial bank in Nepal. Number of regression equations are run by researcher for the study and the final conclusion drawn from all these analysis is that dividend changes provide information about the level of profitability in subsequent years, incremental to market and accounting data. Hence, dividend changes are positively related to earning changes in each of the two years after the dividend change. The other model followed by this study is;

$$
\begin{aligned}
& (\mathrm{Er}-\mathrm{Er}-1) / \mathrm{P}-1=\alpha 0+\alpha 1 \mathrm{R} \Delta \mathrm{DIV} 0+\varepsilon \mathrm{r} \\
& (\mathrm{Er}-\mathrm{Er}-1) / \mathrm{B}-1=\alpha 0+\alpha 1 \mathrm{R} \Delta \mathrm{DIV}+\alpha 2 \mathrm{ROEr}-1+\varepsilon \mathrm{r} \\
& (\mathrm{Er}-\mathrm{Er}-1) / \mathrm{B}-1=\alpha 0+\alpha 1 \mathrm{DPC} 0 \times \mathrm{R} \Delta \mathrm{DIV} 0+\alpha 2 \mathrm{DNC} 0 \times \mathrm{R} \Delta \mathrm{DIV} 0+\alpha 3 \\
& \mathrm{ROEr}-1+\alpha 4\left(\mathrm{E}_{0}-\mathrm{E}_{-1}\right) / \mathrm{B}_{-1}+\varepsilon \mathrm{r} \text {. } \\
& \mathrm{Er}=\alpha 0+\alpha 1 \mathrm{DPC} 0 \times \mathrm{R} \Delta \mathrm{DIV} 0+\alpha 2 \mathrm{DNC} 0 \times \mathrm{R} \Delta \mathrm{DIV} 0+\alpha 3 \mathrm{E}-1+\alpha 4 \mathrm{~B}-1+\alpha 5 \\
& \text { P-1 }+\alpha 6 \text { DIV }-1+\alpha 7 \text { E0 }+\varepsilon r
\end{aligned}
$$

Where,

$\mathrm{E}_{\mathrm{r}}=$ Earnings in year $\mathrm{t}$ relative to the dividend event year.

$\mathrm{R} \Delta \mathrm{DIV}=$ Change in dividends.

DPC $(\mathrm{DNC})=$ A dummy variable that equation for dividend increase (decrease).

ROE $=$ Return on Equity

$\mathrm{P}_{-1}=$ The market value of equity at the beginning of the dividend event year.

$\mathrm{B}_{-1}=\mathrm{Lag}$ book value per share

$\mathrm{DIV}_{-1}=$ total common dividend in the year before the dividend change.

Researchers run series of regression equations and the impact of dividend changes on future profitability of U.S. companies are analyzed. The finding of the initial analysis indicates that the impact of dividend change is significant in the respective years earning change whereas, the impact is insignificant in subsequent years of dividend distribution. However, in modified regressed models, the result indicated significant impact of dividend changes on future profitability. The result, thus, strongly supports the information content of dividend hypothesis. 


\subsection{The Data}

The population of this study is all 29 Commercial Banks presently operating in Nepal. However, not all commercial banks are regularly paying cash dividend. Researchers, thus, applied judgement sampling technique while selecting sample banks. As such 13 commercial banks listed in Nepal Stock Exchange that are paying regular cash dividends have been selected as sample commercial banks for this study. The study is conducted taking panel data analysis and study period covers years from 2001 to 2012 but for some banks only 3 and 4 fiscal years will be taken due to unavailability of data. Since the analysis is based on secondary data analysis, all required data are collected from the annual reports of respective commercial banks.

\subsection{Data Collection Procedure}

This study is based on secondary data analysis. Hence data required for the research are collected from the annual report of banks from the website of respective commercial banks and also from annual bank supervision report of NRB.

\subsection{Data Analysis Methods}

To examine the impact of cash dividend on share price of commercial banks in Nepal, we set null hypothesis that there is no significant impact of research variables on share prices of commercial bank. Further, to examine the impact of dividend on future profitability, we set null hypothesis that there is no significant impact of changes on dividend on future profitability of commercial banks in Nepal. Symbolically,

$\mathrm{H} 0_{1:}$ There is no significant impact of study variables on share prices of different commercial banks.

$\mathrm{HO}_{2}$ : There is no significant impact of changes in dividend on the future profitability of commercial banks.

To test the relationship between variables, regression and correlation analysis is carried out. Besides these inferential tools of data analysis, descriptive analysis of research data is also conducted. To test the co-linearity of the variables developed in regression line, multi-collinear is used. Variables having VIF value less than 10 are accepted for the final regression model and analysis. Besides, for the reliability of the research data, normality test is conducted. Since data set consist only 101 elements, the Shapiro-Wilk test is used. For data variables, which have normality p-value less than 0.05 , are then transformed by using natural logarithm. The transformed variable through natural logarithm is assumed to be normally 
distributed. In addition, for the validity of data, Durbin Watson autocorrelation analysis is carried out. For this study, the DW statistics is assumed to have normal range of $1-2.5$.

\section{Data Analysis and Interpretation}

\section{1 Analysis of Impact of Dividend Policy on Share Prices}

In this section, analysis of the impact of dividend on share prices and future profitability of commercial bank is carried out using the statistical analytical tool of SPSS 16.0.

Descriptive Statistics: Descriptive statistics analysis of key variables is as follows;

Table 1: Descriptive statistics of regression equation (i)

(Here, S.D. is standard of deviation and C.V. is coefficient of variation)

\begin{tabular}{|l|c|l|l|l|l|l|}
\hline & $\mathrm{N}$ & Minimum & \multicolumn{1}{|c|}{ Maximum } & \multicolumn{1}{c|}{ Mean } & \multicolumn{1}{c|}{ S.D. } & \multicolumn{1}{c|}{ C.V. } \\
\hline MP & 101 & 198.00 & 6,830 & $1,377.50$ & $1,301.77$ & 0.94 \\
\hline DY & 101 & 0 & 6.76 & 2.00 & 1.75 & 0.87 \\
\hline RR & 101 & 0.21 & 100.00 & 61.20 & 26.50 & 0.43 \\
\hline $\begin{array}{l}\text { PAT } \\
\text { (in '000) }\end{array}$ & 101 & $57,759.00$ & $1,689,391.00$ & $456,968.00$ & $343,430.00$ & 0.75 \\
\hline EPS & 101 & 6.04 & 175.84 & 54.60 & 39.65 & 0.73 \\
\hline ROE & 101 & 5.72 & 38.79 & 22.50 & 8.00 & 0.36 \\
\hline
\end{tabular}

Table 1 presents the descriptive analysis of key variables i.e. market price, dividend yield, retention ratio, profit after tax, earning per share, return on equity for 101 observations of 13 commercial banks for the study period. The descriptive statistics indicates that among all variables, data of retention ratio and return on equity have relatively lower variation on value than rest of the variables. The correlation analysis of key variables of study is as stated;

Table 2: Correlation Matrix of key variables

\begin{tabular}{|l|l|l|l|l|l|l|}
\hline & \multicolumn{1}{|c|}{ MP } & \multicolumn{1}{c|}{ DY } & \multicolumn{1}{c|}{ RR } & \multicolumn{1}{c|}{ PAT } & \multicolumn{1}{c|}{ EPS } & \multicolumn{1}{c|}{ ROE } \\
\hline MP & 1 & -0.149 & -0.117 & $0.427^{* *}$ & $0.738^{* *}$ & $0.602^{* *}$ \\
\hline DY & & 1 & $-0.378^{* *}$ & 0.172 & $0.346^{* *}$ & $0.376^{* *}$ \\
\hline RR & & & 1 & $-0.201^{*}$ & $-0.255^{*}$ & -0.138 \\
\hline PAT & & & & 1 & $0.505^{* *}$ & $0.596^{* *}$ \\
\hline EPS & & & & & 1 & $0.890^{* *}$ \\
\hline ROE & & & & & & 1 \\
\hline
\end{tabular}

**. Correlation is significant at the 0.01 level (2-tailed).

*. Correlation is significant at the 0.05 level (2-tailed). 
The correlation matrix indicates that the market price, dependent variable of the study, have insignificant negative correlation with dividend yield and retention ratio. Variables i.e. profitafter tax, earning per share and return on equity have significant positive correlation with market price per share.

Linear regression analysis: For each regression, the first row reports the coefficient and the second row reports t-statistics. The empirical regression equation of this analysis is:

Table 3: Linear regression analysis of regression equation (vi)

\begin{tabular}{|c|l|l|l|l|r|r|r|c|}
\hline \multicolumn{2}{|c|}{$\operatorname{In}(M P)=\beta_{0}+\beta_{1}(D Y)+\beta_{2} \ln (R R)+\beta_{3} \ln (P A T)+\beta_{4} \ln (E P S)+\beta_{5}(R O E)$} \\
\hline$\beta_{0}$ & \multicolumn{1}{|c|}{$\beta_{1}$} & $\beta_{2}$ & $\beta_{3}$ & $\beta_{4}$ & $\beta_{5}$ & $\mathrm{R}^{2}$ & $\mathrm{DW}$ & P Value \\
\hline 5.148 & -0.239 & -0.150 & -0.031 & 0.789 & 0.022 & 0.813 & 1.259 & 0.000 \\
\hline $4.294 * *$ & $-10.267 * *$ & $-3.059 * *$ & -0.48 & $4.929 * *$ & 1.395 & & & \\
\hline
\end{tabular}

**. Regression is significant at the 0.05 level (2-tailed).

The result indicated that dividend yield, retention ratio and profit after tax have negative impact whereas, earning per share and return on equity have positive impaction market price per share of commercial banks. The t-statistics of variables indicate that market price has significant negative relation with dividend yield and retention ratio, and significant positive relation with earning per share. Two variables i.e. profit after tax and return on equity has insignificant relation. The findings of two variables; dividend yield and earnings per share is consistent with the finding of Masum (2014), and inconsistent for rest of the variables. The regression equation is further modified leaving variables with insignificant impact and run again for more accurate analysis. The revised regression model is as follows:

$\ln (M P)=\beta_{0}+\beta_{1}(D Y)+\beta_{2} \ln (R R)+\beta_{3} \ln (E P S)+\eta+\lambda+\varepsilon$

The regression analysis of revised model is as follows:

Table 4: Determinants of market price on revised multiple regression model

\begin{tabular}{|l|l|l|l|r|r|r|}
\hline \multicolumn{2}{|l|}{$\operatorname{In}(M P)=\beta_{0}+\beta_{1}(D Y)+\beta_{2}$} & $\ln (R R)+\beta_{3} \ln (E P S)$ \\
\hline$\beta_{0}$ & \multicolumn{1}{|c|}{$\beta_{1}$} & $\beta_{2}$ & $\beta_{3}$ & $\mathrm{R}^{2}$ & $\mathrm{DW}$ & P Value \\
\hline 4.308 & -0.230 & -0.152 & 0.981 & 0.809 & 1.258 & 0.000 \\
\hline $17.928^{* *}$ & $-10.298^{* *}$ & $-3.134^{* *}$ & $19.808^{* *}$ & & & \\
\hline
\end{tabular}

**. Regression is significant at the 0.05 level (2-tailed).

Table 4 shows the result of revised regression model after excluding profit after tax and earnings per share from the basic model. The revised model is written as follows:

In $(\mathrm{MP})=4.308-0.230(\mathrm{DY})-0.152(\mathrm{RR})+0.981(\mathrm{EPS})$ 
The result of revised regression model validates the initial analysis and suggests that dividend yield and retention ratio has significant negative impact, whereas, earning per share has significant positive impact on market price per share. The findings of this study thus support the fact that dividend policy has significant impact on share prices of commercial banks in Nepal. The result is thus consistent with the findings of Masum (2014).

The study is further extended to analyze the impact of dividend on future profitability of commercial bank in Nepal. The analysis is given below:

1.1 Descriptive statistics of variables: Analysis ofdescriptive statistics is as below;

Table 5: Descriptive statistics of rate of change in dividend

\begin{tabular}{|c|c|c|c|c|}
\hline Case of Dividend Change & $\mathrm{N}$ & Average R $\Delta \mathrm{DIV}$ & S.D. on R $\Delta$ DIV & C.V. \\
\hline Increase & 57 & 431.68 & 1033.76 & 0.417 \\
\hline Decrease & 39 & -47.41 & 32.18 & 1.47 \\
\hline No Change & 5 & 0 & 0 & \\
\hline Total & 101 & & & \\
\hline
\end{tabular}

Table 5 indicates descriptive analysis of the dividend change cases of sample commercial banks. The descriptive analysis indicate that out of total 101 observations, 57 observations are of dividend increase, 39 observations are of dividend decrease and 5 observations are of no change in dividend rate. The average rate of increase in dividend is $431.68 \%$, whereas the average rate of dividend decrease is $47.41 \%$. The coefficient of variance indicates that there is moderate level of variance in the data of dividend increase, whereas in case of dividend decrease, coefficient of variation is relatively high. Correlation analysis of key variables is as below:

Table 6 represents the correlation between key variables of this study. The coefficient of correlation analysis indicates that R $\triangle \mathrm{DIV}$ has positive correlation with DPS and has negative correlation with all other variables. This indicates that any change in DPS, R $\triangle \mathrm{DIV}$ also changes in same direction and in case of other variables; EPS, price, $\mathrm{BV}$ and ROE, the R $\triangle \mathrm{DIV}$ will change in opposite direction. Amongst these variables, the correlation of R $\triangle \mathrm{DIV}$ is significantly negative with EPS, MP and BV. Higher correlation can be observed between variable EPS and ROE, EPS and BV and ROE and BV since the coefficient of correlation of these pair variables are near +1 . 
Table 6: Correlation Matrix of key variables

\begin{tabular}{|l|l|l|l|l|l|l|}
\hline & $\operatorname{In}(\mathrm{DPS})$ & $\operatorname{In}(\mathrm{EPS})$ & $\operatorname{In}(\mathrm{MP})$ & $\operatorname{In}(\mathrm{BV})$ & $\mathrm{ROE}$ & $\mathrm{R} \Delta \mathrm{DIV}$ \\
\hline $\operatorname{In}(\mathrm{DPS})$ & 1 & $.685^{* *}$ & $.368^{* *}$ & $.646^{* *}$ & $.709^{* *}$ & 0.028 \\
\hline $\operatorname{In}(\mathrm{EPS})$ & & 1 & $.775^{* *}$ & $.950^{* *}$ & $.954^{* *}$ & $-.236^{*}$ \\
\hline $\operatorname{In}(\mathrm{MP})$ & & & 1 & $.776^{* *}$ & $.718^{* *}$ & $-0.282^{* *}$ \\
\hline $\operatorname{In}(\mathrm{BV})$ & & & & 1 & $.874^{* *}$ & $-.282^{* *}$ \\
\hline ROE & & & & & 1 & -0.185 \\
\hline R $\triangle$ DIV & & & & & & 1 \\
\hline
\end{tabular}

**. Correlation is significant at the 0.01 level (2-tailed).

*. Correlation is significant at the 0.05 level (2-tailed).

\section{Linear regression analysis:}

A multiple linear regression model is used in this study to determine the impact of dividend change on future profitability of commercial banks. The p-value of explanatory variables is used to test the hypothesis at 5\% significance level.For each regression, the first row reports the coefficient and the second row reports tstatistics.

For the analysis of the impact of dividend change on future profitability of commercial banks of Nepal, series of regression models are analyzed. We first followed the basic specification model applied by Nissim and Ziv (2001). The regression model analyzed the impact of one independent variable i.e. rate of change in dividend on the earning changes of respective year, subsequent year 0 and year 1 deflated by lag price. The basic assumption is that its earnings measure profitability of commercial bank. So in the study of future profitability, the earnings of subsequent year are regressed with rate of change in dividend declaration year.

Table 7: Regression of Future Earnings Change, Deflated by Price on Dividend Change

\begin{tabular}{|l|l|l|l|l|l|}
\hline \multicolumn{2}{|l|}{$\left(\mathrm{E}_{\mathrm{r}}-\mathrm{E}_{\mathrm{r}-1}\right) / \mathrm{P}_{-1}=\alpha_{0}+\alpha_{1} \mathrm{R} \Delta \mathrm{DIV}_{0}+\varepsilon_{\mathrm{r}}$} & & \\
\hline $\mathrm{R}$ & $\alpha_{0}$ & $\alpha_{1}$ & $\mathrm{R}^{2}$ & $\mathrm{DW}$ & P Value \\
\hline \multirow{2}{*}{0} & 0.294 & 0.000 & 0.056 & 1.777 & 0.017 \\
\cline { 2 - 6 } & 1.813 & $2.428^{*}$ & & & \\
\hline \multirow{2}{*}{2} & 0.361 & 0.000 & 0.005 & 2.037 & 0.488 \\
\cline { 2 - 6 } & 2.380 & 0.696 & & & \\
\hline \multirow{2}{*}{2} & 0.394 & -0.000 & 0.003 & 1.819 & 0.587 \\
\cline { 2 - 6 } & 2.682 & -0.545 & & & \\
\hline
\end{tabular}

*. Regression is significant at the 0.05 level (2-tailed).

Table 7 indicates that dividend change is positive with earning changes in current year and the subsequent year 1. However, the relation is significant only in the year 0 . However, in the subsequent years of dividend declaration, the relationship is 
insignificant which indicates that the rate of change in dividend does not have significant impact on the future earning of sample commercial banks. The result is consistent with the findings of Nissim and Ziv (2001).

The $\mathrm{R}^{2}$ value of the analysis in year 0,1 and 2 is also very low i.e. $5.60 \%, 0.5 \%$ and $0.3 \%$. This indicates that very low variation in dependent variables i.e. earning changes is explained by the independent variable i.e. rate of change in dividend. Hence, the regression equation is required to analyze with other variables that may influence the dependent variable.

The deflator i.e. price in equation (ii) is market price and thus reflects market fluctuation and expectation of price change. Thus to make the study variable more stable and accurate, the rate of change in earning is deflated by book value of stocks rather than market price. The regression analysis is thus, further carried out by taking changes in earning deflated by book value per share, as dependent variable, and taking rate of change in dividend and return on equityas two independent variables. The regression equation added lagged ROE into the initial analysis as current year ROE is positively correlated with earnings and the relation is significant. The equation is extended to analyze whether the ROE communicate some information about future earning changes as well.For this purpose the following regression equation has been regressed:

$$
\left(\mathrm{E}_{\mathrm{r}}-\mathrm{E}_{\mathrm{r}-1}\right) / \mathrm{B}_{-1}=\alpha_{0}+\alpha_{1} \mathrm{R} \Delta \mathrm{DIV}_{0}+\alpha_{2} \mathrm{ROE}_{\mathrm{r}-1}+\varepsilon_{\mathrm{r}}
$$

Table 8 shows that in both year 1 and year $2, \alpha 1$ is negative and insignificant and $\alpha 2$ is negative. However, $\alpha_{2}$ is insignificant in year 1 and significant in year 2 . This indicates that both the rate of change in dividend and ROE are not informative about the future profitability and do not support the information content hypothesisof dividend. The finding is in contrast to the finding of Nissim and Ziv (2001) which showed the positive and significant impact of dividend changes on future profitability of companies in the U.S.

Table 8: Summary Statistic from Regression of Future Earnings Change, Deflated by Book Value, on the Dividend Change and lag Return on Equity

\begin{tabular}{|c|c|c|c|c|c|c|}
\hline \multicolumn{7}{|c|}{$\left(\mathrm{E}_{\mathrm{r}}-\mathrm{E}_{\mathrm{r}-1}\right) / \mathrm{B}_{-1}=\alpha_{0}+\alpha_{1} \mathrm{R} \Delta \mathrm{DIV}_{0}+\alpha_{2} \mathrm{ROE}_{\mathrm{r}-1}+\varepsilon_{\mathrm{r}}$} \\
\hline $\mathrm{R}$ & $\alpha_{0}$ & $\alpha_{1}$ & $\alpha_{2}$ & $\mathrm{R}^{2}$ & DW & P-value \\
\hline \multirow[t]{2}{*}{1} & 3.461 & -0.0004 & -0.125 & 0.032 & 1.918 & 0.198 \\
\hline & $2.043^{*}$ & -0.061 & -1.793 & & & \\
\hline \multirow[t]{2}{*}{2} & 4.070 & 0.000 & -0.139 & 0.049 & 1.886 & 0.087 \\
\hline & 2.449 & -1.274 & $-2.062 *$ & & & \\
\hline
\end{tabular}

*. Regression is significant at the 0.05 level (2-tailed). 
Table 8 further shows that regressed independent variables explain only $3.2 \%$ and $4.9 \%$ of the future earning changes in year 1 and year 2 respectively. This requires an extended analysis of other variables that have bearing of the changes of future earnings.

Thus, adding other independent variables i.e. earning changes of the dividend event year further modifies the regression model. Besides, to analyze the separate impact of dividend change into increase and decrease case, the rate of change in dividend is broken down as two separate variables. Further modified regression equation including these variables is as below;

$$
\begin{aligned}
& \left(\mathrm{E}_{\mathrm{r}}-\mathrm{Er}_{-1}\right) / \mathrm{B}_{-1}=\alpha_{0}+\alpha_{1} \mathrm{DPC}_{0} \times \mathrm{R} \Delta \mathrm{DIV}_{0}+\alpha_{2} \mathrm{DNC}_{0} \times \mathrm{R} \Delta \mathrm{DIV}_{0}+\alpha_{3} \mathrm{ROE}_{\mathrm{r}-1}+\alpha_{4} \\
& \left(\mathrm{E}_{0}-\mathrm{E}_{-1}\right) / \mathrm{B}_{-1}+\varepsilon \mathrm{r} .
\end{aligned}
$$

Table 9 explains that in year $1, \alpha 1$ has negative and $\alpha 2$ has positive impact on future earning changes and in year 2 both variables have positive impact. However, the relation of bothvariables of dividend change is insignificant. The result does not improve the result from previous regression models. Besides, the coefficient of lagged return on equity and earning changes of dividend declaration year are also statistically insignificant. The result is inconsistent with the result of Nissim and Ziv (2001), and indicates that dividend change doesnot convey special information regarding future profitability of commercial banks in Nepal.

Table 9
Regression of Future Earnings Change, Deflated by Book Value, Rate of Change in Dividend, lag Return on Equity and Earning Changes of Current

\begin{tabular}{|c|c|c|c|c|c|c|c|c|}
\hline \multicolumn{9}{|c|}{$\begin{array}{l}\left(\mathrm{E}_{\mathrm{r}}-\mathrm{Er}_{-1}\right) / \mathrm{B}_{-1}=\alpha_{0}+\alpha_{1} \mathrm{DPC}_{0} \times \mathrm{R} \Delta \mathrm{DIV}_{0}+\alpha_{2} \mathrm{DNC}_{0} \times \mathrm{R} \Delta \mathrm{DIV}_{0}+\alpha_{3} \mathrm{ROE}_{\mathrm{r}-1}+\alpha_{4}\left(\mathrm{E}_{0}-\mathrm{E}_{-1}\right) / \mathrm{B}_{-1}+ \\
\varepsilon \mathrm{r}\end{array}$} \\
\hline $\mathrm{R}$ & $\alpha_{0}$ & $\alpha_{1}$ & $\alpha_{2}$ & $\alpha_{3}$ & $\alpha_{4}$ & R2 & DW & p-value \\
\hline \multirow[t]{2}{*}{1} & 3.676 & -0.00006 & 0.007 & -0.127 & -0.089 & 0.034 & 1.888 & 0.498 \\
\hline & $2.028^{*}$ & -0.084 & 0.367 & -1.786 & -0.246 & & & \\
\hline \multirow[t]{2}{*}{2} & 4.210 & 0.000 & 0.006 & -0.140 & 0.049 & 0.054 & 1.898 & 0.252 \\
\hline & $2.448^{*}$ & -1.413 & 0.360 & $-2.060^{*}$ & 0.538 & & & \\
\hline
\end{tabular} Year

*. Regression is significant at the 0.05 level (2-tailed).

Here, DPC (DNC) is a dummy variable that equation for dividend increase (decrease). For increase (decrease) case of dividend change DPC (DNC) is 1 and zero otherwise.

Even after themodification of empirical model, the $\mathrm{R}^{2}$ of regressed equations explains very low variation on dependent variable i.e. 3.4\% in year 1 and $5.4 \%$ in year 2 . This indicates that there are several other variables that are significant to the future profitability of commercial banks. 
Despite series of modification in regression model, the result does not improve. Thus, the model now followed the absolute measure to define future profitability i.e. level of profit. The model further employs other control variables; lag earning, lag book value, lag market price of share, lag dividend per share and current year profit. The further modified regression model is:

$$
\begin{aligned}
& \mathrm{E}_{\mathrm{r}}=\alpha_{0}+\alpha_{1} \mathrm{DPC}_{0} \times \mathrm{R} \Delta \mathrm{DIV}_{0}+\alpha_{2} \mathrm{DNC}_{0} \times \mathrm{R} \Delta \mathrm{DIV}_{0}+\alpha_{3} \mathrm{E}_{-1}+\alpha_{4} \mathrm{~B}_{-1}+\alpha_{5} \mathrm{P}_{-1}+\alpha_{6} \\
& \mathrm{DIV}_{-1}+\alpha_{7} \mathrm{E}_{0}+\varepsilon_{\mathrm{r}}
\end{aligned}
$$

Table 10: Summary Statistic from Regression of Future Profits on the Dividend

\begin{tabular}{|c|c|c|c|c|c|c|c|c|c|c|c|}
\hline \multicolumn{12}{|c|}{$\begin{array}{l}\mathrm{E}_{\mathrm{r}}=\alpha_{0}+\alpha_{1} \mathrm{DPC}_{0} \times \mathrm{R} \Delta \mathrm{DIV}_{0}+\alpha_{2} \mathrm{DNC}_{0} \times \mathrm{R} \Delta \mathrm{DIV}_{0}+\alpha_{3} \mathrm{E}_{-1}+\alpha_{4} \mathrm{~B}_{-1}+\alpha_{5} \mathrm{P}_{-1}+\alpha_{6} \mathrm{DIV}_{-1}+\alpha_{7} \mathrm{E}_{+\varepsilon_{\mathrm{r}}} \\
\end{array}$} \\
\hline $\mathrm{R}$ & $\alpha_{0}$ & $\alpha_{1}$ & $\alpha_{2}$ & $\alpha_{3}$ & $\alpha_{4}$ & $\alpha_{5}$ & $\alpha_{6}$ & $\alpha_{7}$ & $\mathrm{R}^{2}$ & DW & p-value \\
\hline \multirow[t]{2}{*}{1} & -0.500 & 0.000 & 0.001 & 0.131 & 0.486 & -0.195 & -0.040 & 0.716 & 0.893 & 2.190 & 0.000 \\
\hline & -0.829 & 0.419 & 0.919 & 1.448 & $2.809^{*}$ & $-\overline{3.629 *}$ & -0.318 & $8.077 *$ & & & \\
\hline \multirow[t]{2}{*}{2} & 1.132 & -0.000 & 0.000 & 0.153 & 0.305 & -0.297 & -0.23 & 0.669 & 0.85 & 1.411 & 0.00 \\
\hline & 1.698 & -1.179 & -0.258 & 1.538 & 1.598 & $\begin{array}{l}5.013 * \\
\end{array}$ & 0.075 & $6.811 *$ & & & \\
\hline
\end{tabular}
Change, Instruments for Expected profits and Current Profits

*. Regression is significant at the 0.05 level (2-tailed).

Table 10 presents summary statistics from regressions of equation for $r=1$ and 2 . The coefficient on dividend increase and dividend decrease is essentially zero. Besides, the relation is also statistically insignificant. However, lag book value has significant positive impact on earning level of year 1. However, in year 2, the impact is insignificant. Besides, lag market price has significant negative impact on year 1 and year 2.The result further shows insignificant impact of dividend per share and significant positive impact of current year earning on future earnings.

The $\mathrm{R}^{2}$ figure also improved with the modified regression model as shown by higher $\mathrm{R}^{2}$ i.e. $89.30 \%$ and $85.70 \%$ in subsequent year 1 and 2 of dividend declaration. This indicated that $89.30 \%$ and $85.70 \%$ of the variation in future earning level is accounted by all the independent variables in the test.

The findings of inferential analysis do not indicate significant impact of dividend changes on future profitability of commercial banks in Nepal. The result, thus, does not support information content hypothesis of dividend in Nepal which is inconsistent to the research findings of Nissim and Ziv (2001).

\section{Concluding Remarks}

Using different methodologies, the researchersanalyzed the impact of dividend policy on share price and future profitability of commercial banks in Nepal. The study first analyzes the impact of dividend policy on share price. The finding of the 
study explains that dividend yield and retention ratio have significant negative impact, whereas earning per share has significant positive impact on market price of commercial banks in Nepal. Two variables profit after tax and return on equity have insignificant impact on share price. The study is further extended to analyze the impact of dividend change in future profitability of commercial banks. The analysis indicates that the current year dividend change has significant impact on current year earning changes. The analysis is further carried on by modifying empirical regression equation by adding number of other relevant variables for more accurate analysis. Even after series of regression model, the result does not improve. The result of all subsequent analysis supports the initial findings that the rate of change in dividend does not have significant impact on future profitability of commercial banks in Nepal. Hence, dividend change does not support signalling hypothesis of dividend and do not carry information regarding changes in earning in subsequent years of dividend declaration.

The finding of the study on the impact of dividend policy on share price is consistent with previous studies. However, the study covers more recent study period and wider study area. Hence, this study and its findings are significant to the entire banking industry regarding the factors and its intensity on influencing share prices of commercial banks in Nepal. Besides, the study has taken a lead in analyzing the impact of dividend changes in future profitability of commercial banks in Nepal. The finding would guide bankers to focus on changing rate of dividend distribution to influence the respective year earning changes. However, in the subsequent years, the changes in dividend distribution would not be useful. Thus to influence the future profitability of commercial banks in desired direction, they need to focus on other variables except dividend policy. The result of the study would also be informative to Nepalese shareholders i.e. not to judge the profitability of commercial bank solely on behalf of the dividend distribution pattern.

Researchers, thus, believe that this study provides an insight into the recent scenario of dividend signalling hypothesis in the context of Nepalese banking industry. However, the current analysis faces some restrictions because of the simple nature of model of dividend policy, untested model of dividend and future profitability and the methods employed. Further the study is based on the sample selected from the entire population. The study covers only cash dividend in the study area. The study can be further extended covering both cash dividend and stock dividend covering larger sample and adding other relevant variables on the empirical model. Besides, the study can also be extended in analyzing the impact of dividend on share price and future profitability in other industries and sectors as well. 


\section{REFERENCES}

Adhikari, Nabaraj (2014). Managers' Views on Dividend Policy of Nepalsese Enterprises. NRB Economic Review. Vol. 26. No. 1. pp. 98-104.

Ali, M. B., \& Chowdhury, T. A. (2010). Effect of Dividend on Stock Price in Emerging Stock Market: A Study on the Listed Private Commercial Banks in DSE. International Journal of Economics and Finance. Vol. 2, No. 4. pp. 5264.

Al-Hasan, M. A., Asaduzzaman, M. \& Karim, R. (2013). The Effect of Dividend Policy on Share Price: An Evaluative Study. IOSR Journal of Economics and Finance. Vol. 1, Issue. 4, pp. 06-11.

Al-Malkawi, H. N., Rafferty, M. \& Pillai, R. (2010). Dividend Policy: A Review of Theories and Empirical Evidence. International Bulletin of Business Administration. Issue 9, pp. 179-200.

Almumani, D. M. (2014). Determinants of Equity Share Prices of the Listed Banks in Amman Stock Exchange: Quantitative Approach. International Journal of Business and Social Science. Vol. 05, No. 1, pp. 91-104.

Asquith, P. \& Mullins, D. W. (1983). The Impact of Initiating Dividend Payments on Shareholders' Wealth. The Journal of Business. Vol. 56, No. 1, pp. 77-96.

Baker, H. K, Farrelly, G. \& Edelman, R. (1985). A survey of management views on dividend policy. Financial Management. Vol. 14, No. 3, pp. 78-84.

Baker, H. K., Veit, E. T., \& Powell, G. E. (2001). Factors Influencing Dividend Policy Decisions of Nasdaq Firm. The Financial Review. Vol. 38, pp. 19-38.

Bhole, L. M. (1980). Retained Earnings, Dividends and Share Prices of Indian Joint-Stock Companies. Economic and Political Weekly. Vol. 15, No. 35, pp. M96-M95 +M97-M100.

Black, F., \& Scholes, M. (1970). Dividend Yields and Common Stock Return: A New Metheodology. Alfred P. Sloan School of Management. Vol. 488, No. 70. pp.01-96.

Black, F., \& Scholes, M. (1974). The effects of dividend yield and dividend policy on common stock prices and returns. Journal of Financial Economics, Vol. 1, pp. 1-22.

De, S. (1975). Dividends and Stock Prices: The Indian Experience. Economic and Political Weekly. Vol. 10, No. 36, pp. M62-M63+M65-M67+M69+M71-M72 
Dhillon, U. S., \& Johnson, H. (1994). The Effect of Dividend Changes on Stock and Bond Prices. Journal of Financ. Vol. 49, No. 1, pp. 281-289.

Elton, E. J., Gruber, M. J., \& Gultekin, M. (1981). Expectations and Share Prices. Institute for Operational Research and the Management Sciences. Vol. 27, No. 9, pp. 975-987.

Eriotis, N. (2005). The Effect Of Distributed Earnings And Size Of The Firm To Its Dividend Policy: Some Greek Data. International Business \& Economics Journal. Vol. 4, No. 1. Pp. 67-74.

Garrett, I., \& Priestley, R. (2000). Dividend Behavior and Dividend Signaling. The Journal of Financial and Quantitative Analysis.Vol. 35, No. 1, pp. 173-189.

Gordon, M.. (1963). Optimal investment and financing policy. Journal of Finance. Vol. 18, Issue 2, pp. 264-272.

Grullon, G., Michaely, R., Benartzi, S. \& Thale, R. H. (2005). Dividend Changes Do Not Signal Changes in Future Profitability. Chicago Journals. Vol. 78, No. 5, pp. 1659-1682.

Habib, Y., Kiani, Z. I., \& Khan, M. A. (2012). Dividend Policy and Share Price Volatility: Evidence from Pakistan. Global Journal of Management and Business Research. Vol. 12, No. 5, pp. 79-83.

Hashemijoo, M., Ardekani, A. M. (2012). The Impact of Dividend Policy on Share Price Volatility in the Malaysian Stock Market. Journal of Business Studies Quarterly. Vol. 4, No. 1, pp. 111-129.

Irandoost, R., Hassanzzadeh, R. B. \& Salteh, H. M. (2013). The effect of dividend policy on stock price volatility and investment decisions. European Online Journal of Natural and Social Sciences 2013. Vol. 2, No. 3(s), pp. 51-59.

K.Baker, H., \& e.al, T. K. (2006). How Norwegian Managers View Dividend Poicy. Global Finance Journal. 17, 155-176.

Koch, A. S. \& Sun, A. X. (2004). Dividend Changes and the Persistence of Past Earnings Changes. The Journal of Finance. Vol. 59, No. 5, pp. 2093-2116.

Koirala, P. P., \& Bajracharya, P. P. (n.d.). Nepalese Capital Marekt: Issues and Challenges. Economic Review. Vol. 4, pp. 4-19.

Lintner, J. (1956). Distribution of Incomes of Corporations among Dividends, Retained Earnings, and Taxes,American Economic Review, Vol. 46, No. 2, pp. 97-113. 
Loderer, C. \& Mauer, D. C. (2002). Corporate Dividends and Seasoned Equity Issues: An Empirical Investigation. Journal of Finance. Vol. 47, pp. 201-225.

Malik, F., Gul, S., Khan, M. T., Rehman, S. U. \& Khan, M. (2013). Factors Influencing Corporate Dividend Pay-out Decisions of Financial and NonFinancial Firms. Research Journal of Finance and Accounting. Vol. 4, No. 1, pp. 35-46.

Masum, A. A. (2014). Dividend Policy and Its Impact on Stock Price: A Study on Commercial Banks Listed in Dhaka Stock Exchange. Global Disclosure of Economics and Business. Vol. 3, No. 1, pp. 09-17.

Miller, M. \& Modigliani, F. (1961). Dividend Policy, Growth and the Valuation of Share, Journal of Business, Vol. 34, Issue 4, pp. 411-433.

Mokaya, S.O., Nyang'ara, D. M. \& James, L. T. (2013). The Effect of Dividend Policy on Market Share Value in the Banking Industry; the Case of National Bank of Kenya. International Journal of Arts and Commerce. Vol. 2, No. 2, pp. 91-101.

Nissim, D., \& Ziv, A. (2001). Dividend Changes and Future Profitability. The Journal of Finance, Vol. 56, No. 6, pp. 2111-2133.

Pettit, R. (1972). Dividend announcements, security performance, and capital market efficiency, Journal of Finance, Vol. 27, No. 5, pp. 993-1007.

Srivastava, S. C. (1968, November 30). Share Prices, Dividends and Earnings. Economic and Political Weekly. Vol. 3, No. 48, pp. M89+M91+M93-M95.

Waithaka, S. M., Ngugi, J. K., Ayiabei, J. K., Itunga, J. K. \& Kirago, P. (2012). Effects of dividend policy on share prices: A case of companies in Nairobi Securities Exchange. Prime Journal of Business Administration and Management (BAM). Vol. 2, No. 8 , pp. 642-648.

Walter, J. (1956). Dividend Policies and Common Stock Prices, Journal of Finance, Vol. 11, Issue 1, pp. 29-41

WasfiAlTroudi, \& Maysa'aMilhem. (2013). Cash dividends, retained earnings and stock prices: Evidence from Jordan. Interdisciplinary Journal of Contemporary Research In Business. Vol. 4, No. 12, pp.585-599.

Woolridge, J. R. (1983). Dividend Changes and Security Prices. The Journal of Finance.Vol. 38, No. 5, pp. 1607-1615.

Yilmaz, M. K., \& Gulay, G. (2006). Dividend Policies and Price-Volume Reactions to Cash Dividends on the Stock Market:Evidence from Istanbul Stock Exchange. Emerging Markets Finance \& Trade. Vol. 42, No. 4, pp. 19-49. 